\author{
ANTALYA-KORKUTELİ YEŞİLYAYLA ESKİ KERPİÇ CAMİI \\ RUINED ABOVE MOSQUE IN ANTALYA-KORKUTELİ YeȘILYAYLA
}

\title{
SERKAN KILIÇ*
}

Öz: Bu çalışmada, Antalya’nın Korkuteli ilçesinin Yeşilyayla kasabasında yer alan Osmanlı Dönemi’ne ait Eski Kerpiç Camii ele alınarak tanıtılacaktır. İnșa tarihi bilinmeyen caminin inşasında kabayonu taş ve kerpiç malzeme kullanılmıştır. Dikdörtgen planlı olan camii içten ahşap düz tavan, dıştan ise kırma çatıyla örtülmüştür. Tavanın merkezinde yer alan sembolik kubbe, bağdadi tarzda tasarlanmıştır. Zengin kalemişi süslemelere sahip olan caminin harim bölümünde, çevre ilçe ve köylerde de görülen zengin duvar resimleri mevcuttur. Özellikle yapının içerisindeki Sultanahmet ve Süleymaniye Camii tasvirleri dikkat çekicidir. Yapı plan, malzeme ve süslemeleri bütün ayrıntılarıyla incelenerek hem çevre ilçe, kasaba ve köylerdeki camiler hem de Anadolu Türk Sanatı içerisindeki yeri ve önemi ortaya konulmaya çalışılmıştır. 20. yüzyılın hemen başlarında inşa ettirildiği düşünülen ve mahallî sanatçlların özel becerilerini ortaya koyduğu camilerin tamamında geleneksel ahşap mimarisinin taşradaki şaşırtıcı örneği olması ayrıca önemlidir. Günümüzde ibadete açık olan cami, 2013 yılında Vakıflar Genel Müdürlüğü tarafından aslına uygun bir şekilde restore ettirilmiştir.

Anahtar Kelimeler: Osmanlı • Antalya • Korkuteli • Kerpiç• Camii
Abstract: In this paper, ruined adobe mosque belonging to the Ottoman Period in Yeşilyayla town of Korkuteli, Antalya will be discussed. Stone and adobe materials were used in the construction of the mosque, which was unknown to date. The rectangular mosque is covered with a wooden flat roof and the outside is covered with a cracked roof. The symbolic dome in the center of the ceiling is designed in a vineyard style. There are rich wall paintings of the mosque, which has rich artifact decorations, also seen in the surrounding towns and villages. Especially, the depictions of Sultanahmet and Süleymaniye Mosque within the structure are remarkable. The building plan, materials and decorations were examined in detail and the place and importance of the mosques in the surrounding towns, and villages and the place and importance of them in Anatolian Turkish Art were tried to be put forward. It is also important that the traditional wooden architecture in all of the mosques that were built at the beginning of the twentieth century and where the local artists showed their special skills is a surpri-sing example in the countryside. The mosque, which is now open to worship, was restored in 2013 by the General Directorate of Foundations.

Keywords: Ottoman • Antalya • Korkuteli • Adobe • Mosque

\section{Giriş}

Korkuteli ilçesi, Antalya’nın 60 km kuzeybatısında yer almaktadır. Günümüzde Korkuteli adıyla bilinen ilçe, İbn-i Battuta ile Evliya Çelebi'nin Seyahatnamesinde ve Neşri'de "Istanos" adıyla anılmaktadır. Fatih dönemindeki defterlerde de Korkuteli, İstanos șeklinde kaydedilmiştir'. Evliya Çelebi, Istanos'u ziyaretinde; “Ankara Paşası’nın subaşıllğ̆ hükmünde 150 akçe nahiye kazalarından Murtatova nahiyesi hududunda iki tarafı göklere çıkmış daracık derenin kenarında bin haneli, bağsız ve bahçesiz,

* Dr. Öğr. Üyesi, Akdeniz Üniversitesi, Mimarlık Fakültesi, Mimarlık Bölümü, Antalya. () 0000-0001-9314-5337 | serkankilic@akdeniz.edu.tr

1 Yildiz 2018, 2. 
camili, hamamı ve küçük sultan çarşılı bakımlı bir kasabadır" şeklinde tanımlamaktadır². Bu tanımlamanın 1915’e kadar sürdüğü, aynı tarihte alınan bir kararla, Şehzade Mehmed Korkut'un anısını yaşatabilmek için "Korkuteli" şekliyle yeniden düzenlendiği bilinmektedir ${ }^{3}$. Korkuteli ilçesinin ilçe merkezi dışında 45 adet köyü bulunmaktadır ${ }^{4}$. Değerlendirmeye aldığımız cami, Korkuteli ilçesinin yaklaşı $25 \mathrm{~km}$ kuzeyinde, Osmanlı Dönemi’nde "Andiye" olarak bilinen Yeşilyayla köyünde yer almaktadır ${ }^{5}$.

\section{Yeşilyayla Eski Kerpiç Camii}

Camii Antalya İli, Korkuteli İlçesi, Yeşilyayla Kasabası’nın Yavuz mahallesinde yer almaktadır. Caminin inşa kitabesi bulunmamaktadır. Yapı hakkında Başbakanlık Osmanlı Arşivi ve Vakıflar Genel Müdürlüğü Arşivìnde camii hakkında herhangi bir belgeye rastlanmamıştır. Sadece 1835 yllında, Andiye (Yeşilyayla) köyü imamının Molla Ahmet olduğg ${ }^{6}, 1840$ tarihli arşiv kaydında ise Hasan Hoca isminde bir zatın imamlık yaptığı bilgisine ulaşılmıştır7. Camii, Antalya Kültür ve Tabiat Varlıklarını Koruma Kurulu tarafından 2000 ylında tescillenerek koruma alınmıştır (AKVKKM., 17.08.200 tarihli ve 4687 nolu karar). Yapının envanter fişinde, 1896 yılında Kara Müdür tarafından inşa ettirildiği bilgisine ulaşılmaktadır. Cami, 2013 yllında restore ettirilmiş olup günümüzde ibadete açıktır.

Camiinin beden duvarları restorasyon aşamasında tamamıyla beyaz renkte boyanmıştır. Camiye ait eski fotoğraflardan duvarların temel seviyesine kadar ahşap hatıllar arasına kabayonu taşla örüldüğü üst kotlar da ise kerpiç malzeme tercih edildiği anlaşılmaktadır. Yapının pencere çerçevelerinde, harime giriş kapısında, harim içi üst örtüde, vaaz kürsüsünde ve kadınlar mahfilinde ahşap malzeme; harim içindeki duvarlarda yer alan panolarda ise alçı malzeme kullanılmıştır. Caminin kırma çatısı, alaturka kiremitle kaplanmıştır.

Cami, yaklaşık 11.20x13.23 m ölçülerinde dikdörtgen planlı olup üzeri kırma çatıyla örtülmüştür. Yapının harim duvarları dört yönden ahşap saçakla çevrilmiştir. Caminin beden duvarı kalınlı̆̆ı doğu ve batı duvarda $0.65 \mathrm{~m}$ ile $0.70 \mathrm{~m}$ arasında değişiklik göstermektedir. Kuzey cephe duvar kalınlığı 0.90 $\mathrm{m}$, güney duvar kalınlığı ise 0.80 m olarak tespit edilmiştir (Fig. 1).

Yapının doğu cephesinin güneyinde iki adet 1.49x0.84 m ölçülerinde dikdörtgen formlu, ahşap çerçeveli ve demir parmaklıklı pencere yer almaktadır. Cephenin kuzey köşesine ise harime giriş kapısı yerleştirilmiştir (Fig. 2). Batı cephede ise aynı form ve ölçülere sahip üç adet pencere açılmış olup cephenin kuzey köşesine harime giriş kapısı konumlandırılmıştır. Caminin güney cephesinde, alt ve üstte ikişer adet olmak üzere iki kademeli pencere uygulaması görülmektedir. Alt kottaki pencereler, doğu ve batı cephedeki pencerelerle aynı özelliği taşımaktadır. Alt kottaki pencerelere simetrik olarak yerleştirilmiş üst kot pencereleri daha küçük ölçekli ve dikdörtgen formludur (Fig. 3). Yapının batı cephesinde kalemişi süslemeler görülmektedir. Cephenin saçak kısmına konumlandırılacak şekilde, beş adet dikdörtgen çerçeve çizilmiştir. Çerçevelerin içi ise yukarıdan aşağıya doğru sarkan kıvrık dal motifleriyle süslenmiştir. Cephenin güney köşesinin yakın kısmına ise bir adet çelenk motifi çizilmiștir. Motifler, beyaz zemin üzerine kahverengi ve mavi renk kullanılarak oluşturulmuştur. Caminin kuzey

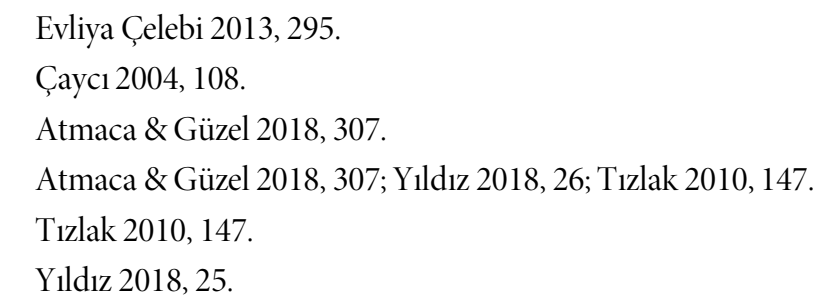




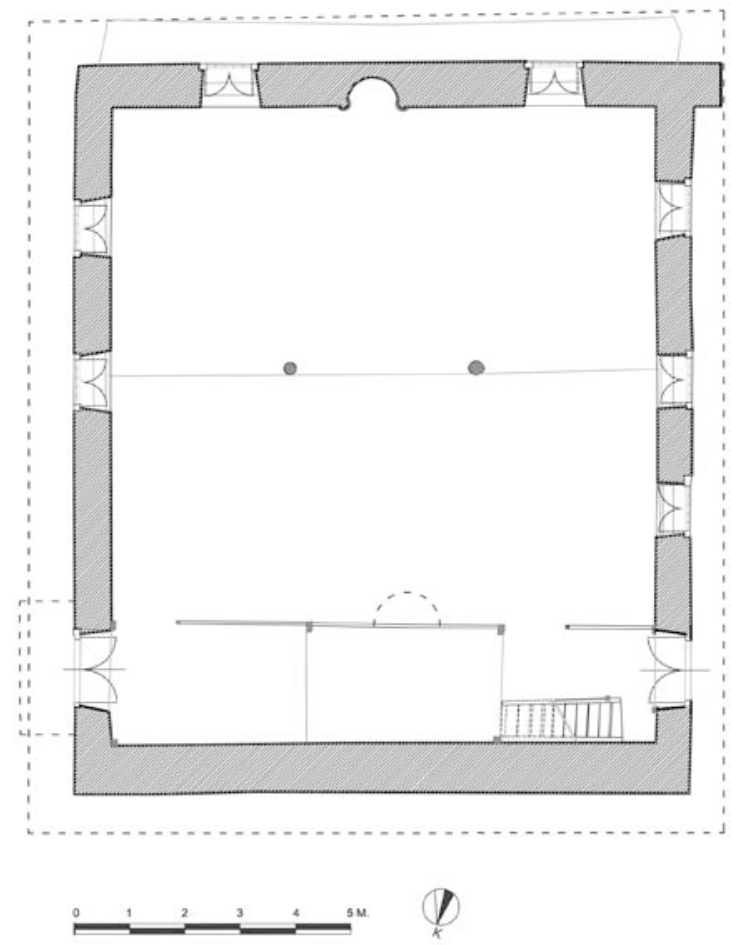

Fig. 1. Yeșilyayla Eski Kerpiç Camii Planı (VBM’den düzenlenerek)

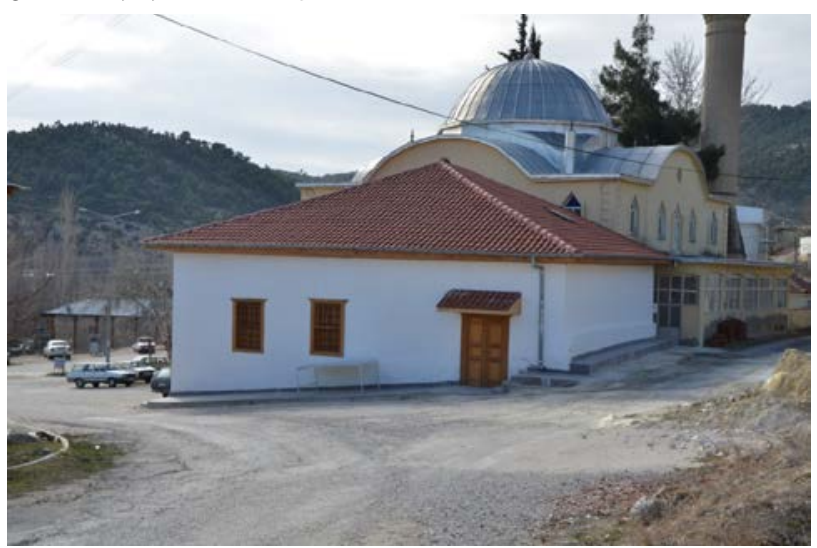

Fig. 2. Yeșilyayla Eski Kerpiç Camii Genel Görünüm

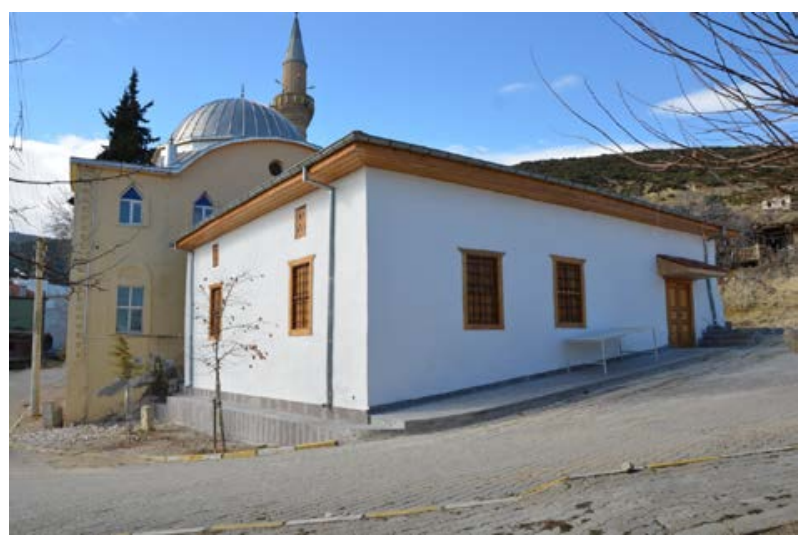

Fig. 3. Yeşilyayla Eski Kerpiç Camii Güneydoğu Cephesi 


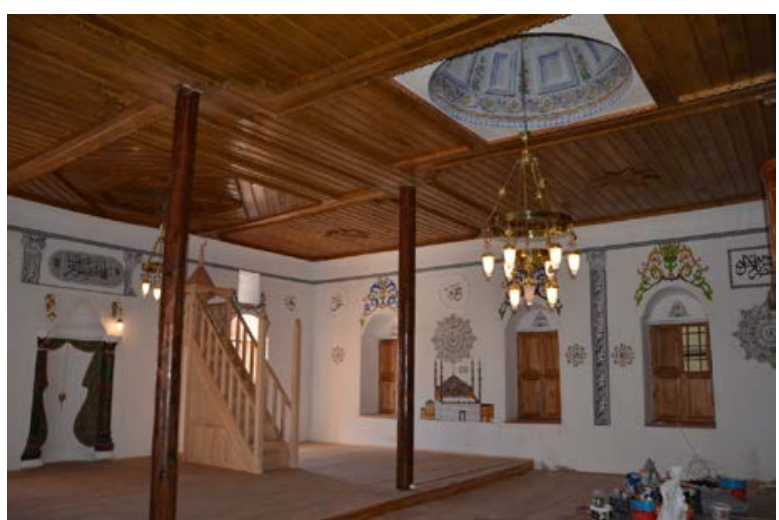

Fig. 4. Yeşilyayla Eski Kerpiç Camii Harim İçi Genel Görünüm

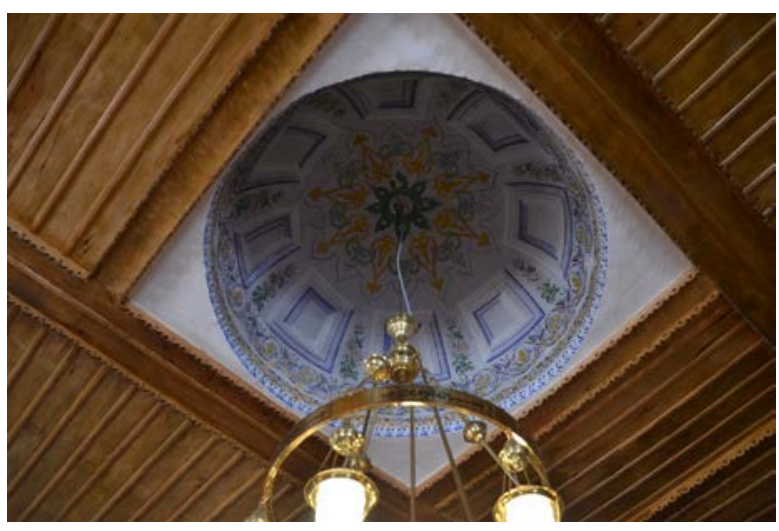

Fig. 5. Yeșilyayla Eski Kerpiç Camii Bă̆dadi Kubbedeki Kalemişi Süslemeleri cephesi hem süsleme hem de pencere düzenlemesi bakımından sağır tutulmuştur.

Harim, 11.59x9.85 m ölçülerinde dikdörtgen planlıdır. Harimin üzeri ahşap düz tavanla örtülmüştür. Tavan, güney yönden iki, kuzey yönden ise dört adet ahşap direklerle desteklenmektedir. Kuzey yöndeki direkler profilli başlıklara sahiptir. Süsleme bakımından zengin olan tavan, yedi panoya ayrılmıştır. Tavanın merkezinde $1.76 \mathrm{~m}$ çapında sembolik bir kubbe yer almaktadır. Bağdadi tarzda yapılmış olan kubbenin iç yüzeyi gri zemin üzerine sarı, yeşil ve mavi renklerin hakim olduğu süslemelerle bezenmiştir. Kubbe göbeği daire içine alınmış yaprak motifiyle süslenmiştir. Dairenin çevresi ise 16 kollu ylldı motifiyle hareketlendirilmiştir. Yıldız kolları, iç içe geçmiş kıvrık dal ve palmet motifiyle doldurulmuştur. Kubbe eteği ile göbeği arasında kalan bölüm, sekiz adet dikdörtgen formlu pencere motifleriyle bezenmiştir. Pencere aralarına ise birer adet yeşil yapraklı ve pembe renkli gül motifleri çizilmiştir. Kubbe eteğinde görülen süslemeler, üç bordür şeklinde düzen-

lenmiştir. İçten birinci bordür, diğer bordürlere nazaran daha geniş tutulmuş olup sprial bir şekilde birbirine bağlanan kıvrık dal motifleriyle süslenmiștir. İçten ikinci bordürün yüzeyi sarı ve kahverengi küçük yaprak motifleriyle, dıştaki bordür ise mukarnası andıran bezemelerle doldurulmuştur. Mihrap önündeki panonun merkezinde kare formlu bir kartuş yer almaktadır. Kartuşun yüzeyine, merkezden ışınsal olarak dışa doğru genişleme gösteren ahşap çıtalar çakılmıştır. Kartuşun kenarları pahlanarak sekizgen formu elde edilmiştir. Kubbe ve mihrap önü panolarının her iki yanında yer alan diğer panoların merkezi ise ince çıtaların çakılmasıyla oluşturulmuş sekiz kollu yıldızlarla süslenmiştir. Harimin kuzeyinde yer alan ve kadınlar mahfilini örten panonun yüzeyi yalın bırakılmıştır. Süsleme açısından zengin olan harim duvarları, beyaz alçı üzerine kalemişi tekniğinde işlenmiş süslemelerle bezenmiştir (Fig. 4-5). Harimin doğu duvarının güney yönünde, 1.50x0.96 m ölçülerinde yuvarlak kemerli iki adet pencere açılmıştır. Batı duvarda ise aynı form ve ölçülere sahip üç adet pencere yer almaktadır. Güney duvarın merkezine mihrap, doğu köşesine ise vaaz kürsüsü yerleştirilmiștir. Mihrabın her iki yanında yer alan pencereler, iki kademelidir. Alt kottaki pencereler, diğer cephedeki pencerelerle aynı özelliği taşımaktadır. Alt kottaki pencerelerin hemen üzerine açılan üst kot pencereleri daha küçük ölçekli olup dikdörtgen formlu ve basit ahşap kafeslidir. Mihrabın hemen batısında yer alan ahşap minber orijinal değildir.

Harim, kuzey duvar hariç, tavan seviyesinin hemen altından başlayarak üç yönden tek sıra bordürle çevrelenmektedir. Bordürün içi, birbirini takip eden gri renkteki küçük palmet motifleriyle bezenmiştir. Harimin doğu, batı ve güney duvarlarında, daire formlu alçı panolar yer almaktadır. 
Panoların yüzeyinde beyaz zemin üzerine siyah renkte; Allah, Muhammed, dört halife ile Hasan Hüseyin isimleri yazmaktadır. Doğu duvardaki pencere alınlıkları, aşağıdan yukarıya doğru daralma gösteren bitkisel motifle, yuvarlak kemerlerin hemen üzeri ise vazo içerisinden çıkan kıvrık dal motifleriyle süslenmiştir. Kıvrık dalların uçları ise palmet ve rumi motifleriyle hareketlendirilmiştir. İki pencerenin tam ortasına gri, kahverengi ve beyaz renklerle Sultanahmet Camisi resmedilmiştir (Fig. 6). Kuzey yöndeki pencerenin hemen solunda, kompozit başlğga sahip bir sütun motifi çizilmiştir. Sütunun içi ise çiçek ve kıvrık dal motifleriyle doldurulmuştur. Sütunun her iki yanına, birer adet bitkisel rozetler yerleştirilmiştir. Harimin batı duvarında yer alan pencerelerin alınlıkları ile yuvarlak kemerlerinin hemen üzeri doğu duvarda görülen benzer süslemelerle bezenmiştir. Güney yöndeki iki pencerenin tam ortasına gri, kahverengi ve beyaz renklerle Süleymaniye Camisi işlenmiştir (Fig. 7). Caminin hemen üzerinde kıvrık dal ve yapraklarla oluşturulmuş büyük bir rozet motifi yer almaktadır. Kuzey yöndeki pencerelerin ortasına ise doğu duvarda görülen benzer sütun ve bitkisel rozet motifi çizilmiştir. Batı duvarın kuzeyinde, bordürün hemen altına gelecek şekilde konumlandırılmış dikdörtgen bir çerçeve içerisinde, Ya Hazreti Bilal-i Habeşi ibaresi yazmaktadır. Yazıtın hemen altında ise benzer büyük bitkisel rozet motifi işlenmiştir. Harimin güneyi yerden bir basamak yüksek tutulmuş olup güney duvarın merkezine mihrap yerleștirilmiştir.

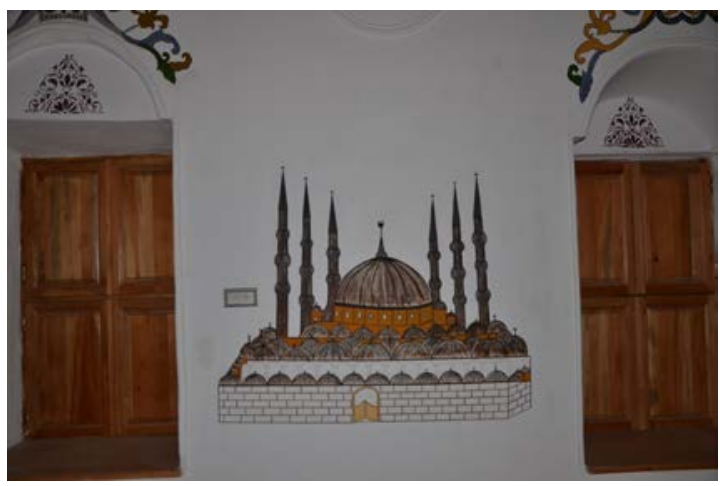

Fig. 6. Yeşilyayla Eski Kerpiç Camiinin Doğu Duvarıdaki Sultanahmed Camii Resmi

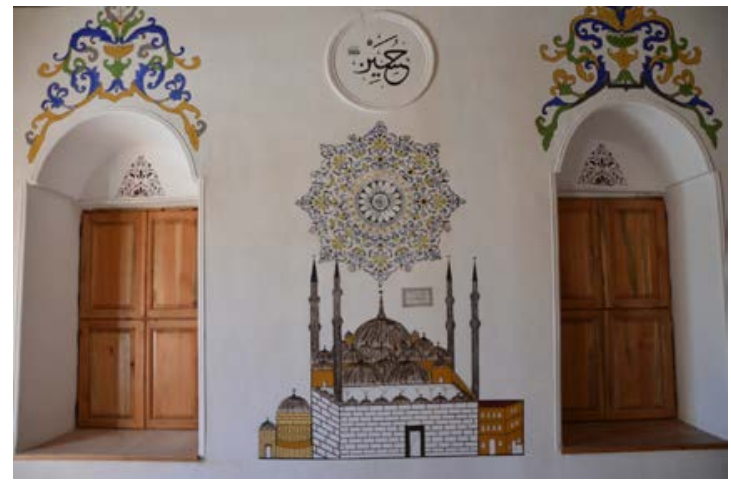

Fig. 7. Yeşilyayla Eski Kerpiç Camii'nin Batı Duvarındaki Süleymaniye Camii Resmi

Güney duvarın ortasındaki yarım daire planlı mihrap, $0.94 \mathrm{~m}$. genişliğinde ve $2.44 \mathrm{~m}$. yüksekliğindedir. Mihrap nişi, köşelere toplanmış beyaz zemin üzerine yeşil renkte perde motifiyle bezelidir. Perdelerin birleștiği noktadan yukarıdan aşağıya doğru zincirle sarkıtılan ve ucunda tanrısal ışığı ve nuru simgelediği düşünülen bir kandil motifi yer almaktadır ${ }^{8}$. Nişin her iki yanında ise duvara gömülü şekilde yerleştirilmiş sütunceler yer almaktadır. Sütunceler basit profilli kaide ve başlıklarla sahiptir. Sütunce ve kaideler yeşil ve mor renkte boyanmıştır. Başlıklar ise yeşil ve pembe renkteki palmet ve yaprak motifleriyle süslenmiştir. Süsleme açısında yalın bırakılan mihrap kavsarası, aşağıdan yukarıya doğru üç kademeli olarak daralmaktadır. Mihrabın hemen üzerinde, yatay dikdörtgen formunda kelemişi tekniğinde düzenlenmiş bir çerçeve yer almaktadır. Çerçevenin yüzeyinde, gri zemin üzerine siyah renkte küllemâ dehale aleyhâ zekeri yüzylle'l-mihrâb yazmaktadır. Çerçeve, her iki yönden kalemişi tekniğinde korint başlıklı sütunlarla sınırlandırılmıştır. Harimin kuzey duvarının zemin seviyesi, dikdörtgen panolarla hareketlendirilmiştir. Panolar atlamalı olarak kırmızı, yeşil ve pembe renkteki perde motifleriyle süslenmiştir (Fig. 8).

\footnotetext{
8 Arık 1976; Renda 1977.

9 Ali Imran Suresi 37. Ayet.
} 


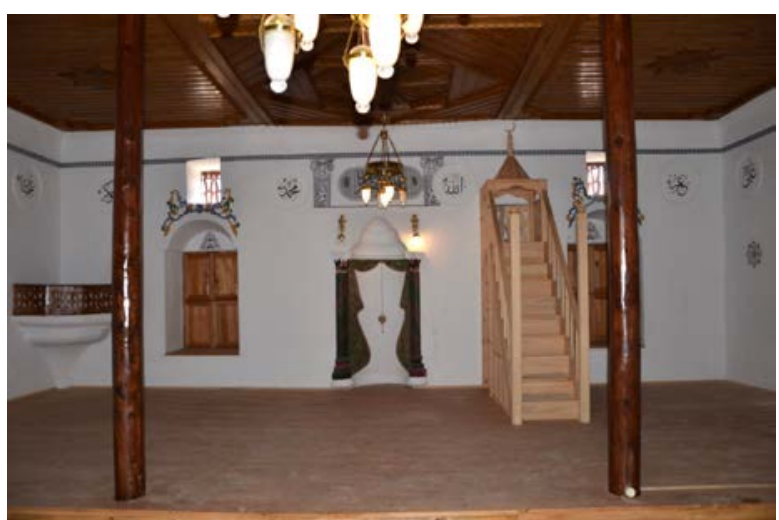

Fig. 8. Yeşilyayla Eski Kerpiç Camii Güney Duvarı

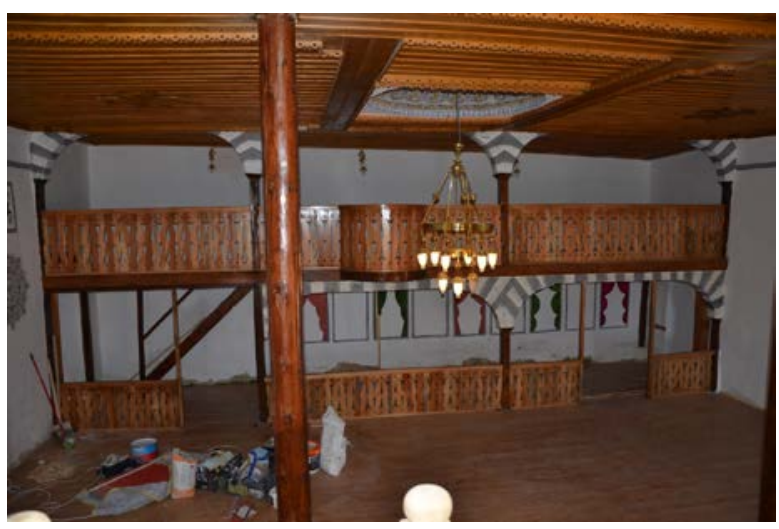

Fig. 9. Yeşilyayla Eski Kerpiç Camii Kuzey Duvarı

Vaaz kürsüsü harimin güneydoğu köşesine konumlandırılmış olup yerden $1.51 \mathrm{~m}$. yüksek tutulmuştur. Kürsü korkuluğu, profilli ahşap çıtalarla oluşturulmuştur.

Harimin kuzeyine konumlandırılan kadınlar mahfili, kuzey duvarı boyunca uzanmaktadır. Mahfile, kuzeybatı köşede yer alan dokuz basamaklı merdivenle çıkılmaktadır. 9.78x2.12 m ölçülerinde olan mahfil, güney yönden dört, kuzey köşelerden ise iki adet ahşap direklerle taşınmaktadır. Güney yöndeki direklerle aynı hizada olan ikinci kattaki direkler, ahşap tavanı desteklemektedir. Her iki kattaki direkler basit profilli başlıklara sahiptir. Alt kattaki direkler doğu yönünde birbirine Bursa Tipi kemerlerle bağlanmıştır. Üst kattaki direklerde ise yandan kesitli yastıklar tercih edilmiştir. Kemer ve yastıkların yüzeyi, mermer görünümü kazandırmak amaciyla gri ve beyaz renkte boyanmıştır. Mahfilin güney cephesinin merkezi, mihraba doğru çıkıntı yaparak balkon şekilde düzenlenmiştir. Alt ve üst kattaki mahfil korkulukları basit profilli ahşap şebekelerden meydana gelmektedir (Fig. 9).

\section{Değerlendirme}

Antalya’nın Korkuteli ilçesine bağlı Yeşilyayla köyünde yer alan caminin inşa tarihi bilinmemektedir. Yapılan literatür çalışmalarında Yeşilyayla' da toplam yedi adet caminin olduğu tespit edilmiş$\operatorname{tir}^{10}$. Ancak arşiv kayıtları ile genel literatür çalışmalarında, Yeşilyayla'daki camii hakkında bir bilgiye ulaşılmaması dikkat çekicidir. Antalya Kültür ve Tabiat Varlıklarını Koruma Kurulu tarafından 2000 yllında tescillenen caminin envanter fişinde, 1896 yılında Kara Müdür tarafından inşa ettirildiği bilgisine ulaşılmaktadır. Ancak yapılan araştırmalar neticesinde bu bani hakkında herhangi bir bilgiye rastlanmamıştır. Caminin mimari özellikleri ile birlikte kalemişi süslemeleri dikkate alındığında yapının 19. yüzyıl dönem özelliği taşıdığı anlaşılmaktadır. Aynı şekilde, 1835 ve 1840 yılına ait belgelerden köyde camii imamlarının görev aldığı bilgisinden yola çıkarak, caminin 1835 yılından önce inşa ettirilmiş olabileceği düşünülmektedir.

Antalya' daki ahşap tavanlı camii ve mescitler genel itibarıly incelendiğinde, beden duvarlarının, ahşap hatıllar atılarak kerpiç malzemeyle örüldügü ve çamurla sıvandığı anlaşılmaktadır. Harim bölümünün ise badanalandıktan sonra kalemişi süslemelerle bezendiği bilinmektedir. Yöresel mimari geleneğin özelliklerini temsil eden bu tarz yapılar, Anadolu'nun ilçe ve köylerinde benzer şekilde inşa edilmiştir. Ahşap direkli ve ahşap tavanlı camilerin inşa malzemeleri dikkate alındığında; daha ucuz ve daha hızlı temin edilebilen malzemelerin tercih edildiği görülmektedir.

10 Erten 1948, 89; Yıldız 2018, 92-96. 


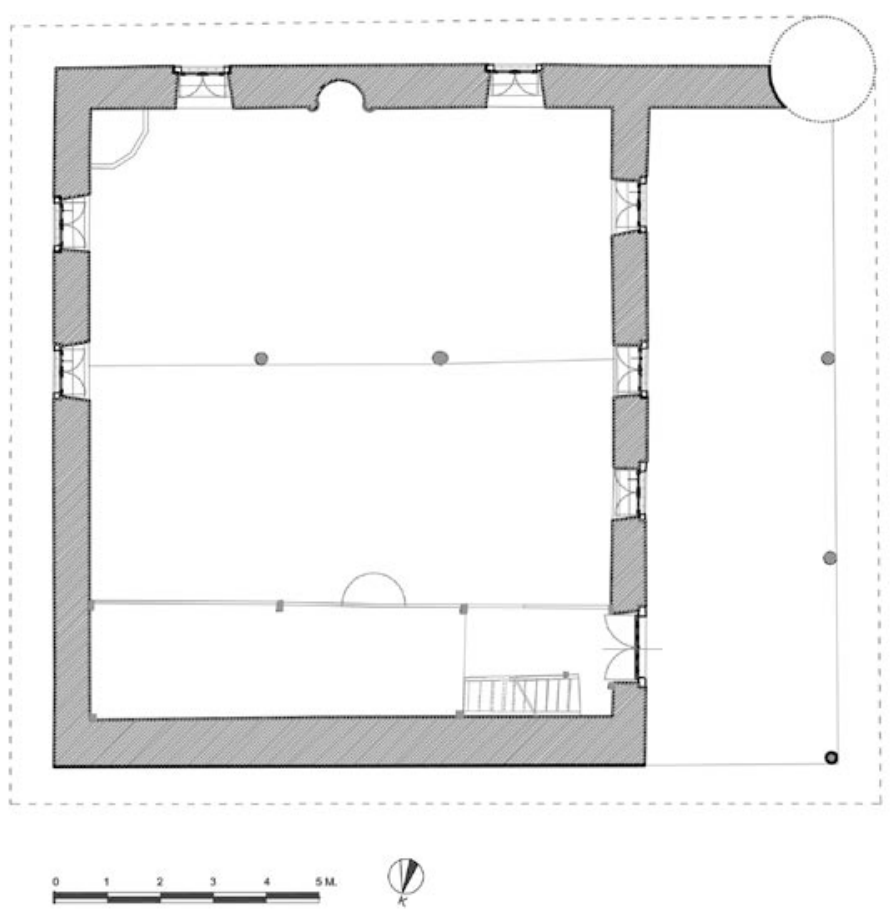

Fig. 10. Yeşilyayla Eski Kerpiç Camii Restitüsyon Planı (VBM'den düzenlenerek)

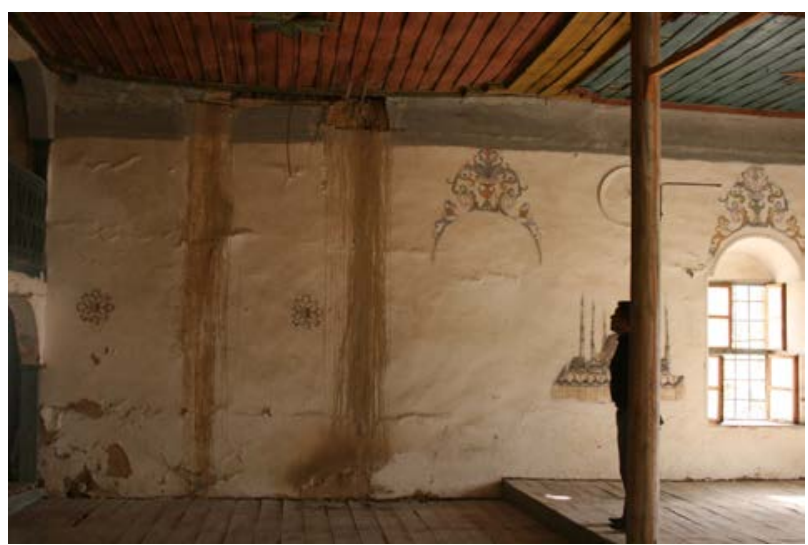

Fig. 11. Yeşilyayla Eski Kerpiç Camii Restorasyon Öncesi Durumu

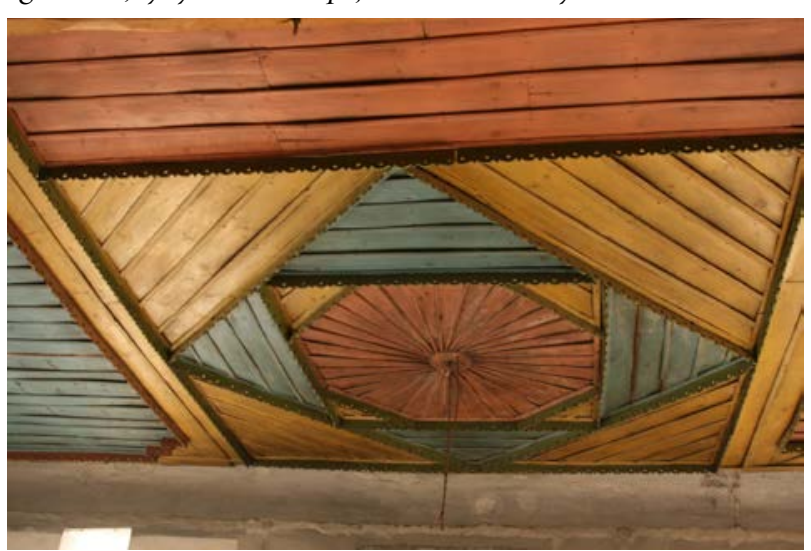

Fig. 12. Yeşilyayla Eski Kerpiç Camii Restorasyon Öncesi Tavan Süslemelerinden Detay 
Antalya-Elmalı'daki Eskihisar Köyü Camii (19. yüzyll), Kütük Camii (19. yüzyll), Bayralar Köyü Camii (19. yüzyıl) ${ }^{11}$, Akseki'deki Sarıhacılar Köyü Camii (19. yüzyıl) ${ }^{12}$, Eskişehir-Sivrihisar'daki Sadıkbağı ve Demirci Köyü Camii ${ }^{13}$, Burdur-Merkez'de Gazi (Çiloğlu) Camii (19. yüzyll), Şeyh Sinan Camii (1776), Sadenzade Mustafa Hatipoğlu Camii (1861); Burdur-Çavdır'da Bayır Camii (19. yüzyl); BurdurKemer'de İbrahim Çavuş (Yukarı) Camii (1866); Isparta-Eğirdir'de Ali Ağa Camii (1712); IspartaSenirkent'te Şeyhler Camii (1854); Isparta-Şarkikaraağaç’ta Kürt (Alaca Mescid-Yukarı Çarşı) Camii (1876); Gülşehir-Gümüşkent Köy Odası (1939) ${ }^{14}$, Kurşehir'deki Mucur Camileri (19. ve 20. yüzyll) ${ }^{15}$ Giresun'da 19. yüzyılda inşa edilmiş Tekke Köyü Hacı Abdullah Halife Camisi ${ }^{16}$ ve 1903 yllında inşa edilen Mersin-Erdemli ilçesi Güzeloluk Köyü’ndeki Camii ${ }^{17}$ gibi yapılar Yeşilyayla köyünde inşa edilmiş olan ahşap tavanlı camil ile inşa tekniği ve süslemeleri bakımından büyük benzerlik göstermektedir. Camii içerisinde görülen kalemişi süslemelerden İstanbul'un simgelerinden olan Sultanahmet ve Süleymaniye camilerinin olması dikkat çekicidir. Böyle bir cami resminin işlenmesi, İstanbul'a özlem duyulduğunu ve bu özlemi de en iyi şekilde cami resimleriyle giderme yoluna gittikleri ileri sürülebilinir.

Caminin 2013 yllına ait rölöve raporuna göre özgün mimarisinde batıda bir son cemaat yerinin, güneybatı köşede ise ahşap bir minarenin olduğu anlaşılmaktadır. Ancak 1976 ylında caminin hemen batısındaki yeni caminin inşasında, son cemaat yeri ile minarenin yıkıldığı, çatının ise harim dış duvarı hizasından kesilerek kerpiç ile kapatıldığı anlaşılmaktadır. Bu bilgilerden yola çıkılarak bir restitüsyon planı hazırlanmıştır (Fig. 10).

Caminin restore edilmeden önceki fiziki durumu göz önüne alındığında, duvarlarında derin çatlakların olduğu, ahşap tavanda göçüklerin meydana geldiği, duvar sıvalarının döküldüğü, kalemişi süslemelerin ise nem ve yağmur sularından dolayı silindiği anlaşılmaktadır (Fig. 11). Yapılan restorasyon sonrasında çatlak ve göçükler tamir edilmiş olup kalemişi süslemelerin silinen yerleri aslına uygun bir şekilde tamamlanmıştır. Ancak harimi örten ahşap tavan ve kadınlar mahfili tamamıyla yenilenmiş olması caminin özgünlüğünü kaybetmesine neden olmuştur (Fig. 12).

Korkuteli-Yeşilyayla Belediye Başkanlığı tarafından Vakıflar Genel Müdürlüğü’ne yazılan belgede; caminin duvarlarında göçme ve çatlamaların olduğu, camii etrafında yaşayan insanlar için büyük tehlike arz ettiği ve bundan dolayı yapının yıktırılması gerektiği huşusunda talepte bulunulmuştur (sayı no: B.02.01.VGM.0.10.00./07-08/ (92)). Cami her ne kadar metruk bir halde olsa da yıkımı gerçekleşmemiştir. Antalya Vakıflar Bölge Müdürlüğü tarafından yapılan onarımlar sonrasında geç dönem Osmanlı eseri olan bu anıtın gelecek nesillere aktarımı sağlanmıştır.

Sonuç olarak; Anadolu'da ahşap tavanlı camii yapma geleneği, 13. yüzyıldan başlayarak 20. yüzyılın başlarına kadar devam etmiştir. İncelediğimiz cami de; Niğde, Ankara, Konya, Yozgat, Kastamonu, Aydın, Isparta, Denizli ve Eskişehir gibi şehirlerde inşa edilen ahşap tavanlı ve kalemişi süslemeli camilerin yapılması geleneğini, Antalya-Korkutelinnde devam ettiren örnek olması bakımından önem taşımaktadır.

\footnotetext{
11 Kilıç 2018, 407-425.

12 Tay 2017, 127-145.

13 Parla 2010, 27-33.

14 Tay 2018, 243-252.

15 Tay 2017, 691-729.

16 İltar 2014, 70.

17 Tay 2011, 270.
} 
AKVKKM

Arlk 1976

Atmaca - Güzel 2018

Evliya Çelebi

Erten 1948

Çaycı 2004

İltar 2014

Kılıç 2018

Parla 2010

Renda 1977

Tay 2011

Tay 2017

Tay 2017

Tay 2018

Tızlak 2010

Yıldız 2018

\section{BİBLIYYOGRAFYA}

Antalya Kültür Varlıklarını Koruma Kurulu Müdürlüğü (AKVKKM.) 17.08.200 tarihli ve 4687 nolu karar.

R. Arık, Batılllașma Dönemi Anadolu Tasvir Sanatı. İstanbul 1976.

E. Atmaca - Ö. Güzel, "Antalya’nın Korkuteli İlçesi’nin Köy Adları”. Avrasya Uluslararası Araşttrmalar Dergisi 6/15 (2018) 304-328.

Evliya Celebi, Günümüz Türkçesiyle Evliya Celebi Seyahatnamesi. Cilt 1.

2. Kitap. İstanbul 2013.

S. F. Erten, Antalya Tarihi. Antalya 1948.

A. Çaycı, "Korkuteli (Istanoz) Tarihi ve Korkuteli Alaaddin Camii Üzerine Bir Araştırma”. Selçuk Üniversitesi Türkiyat Araştırmaları Dergisi (2004) 107-128.

G. İltar, "Tekke Köyü Hacı Abdullah Halife Camisi Duvar Resimleri”. Vakıflar Dergisi 42 (2014) 69-80.

S. Kılıç, "Elmalıddaki Ahşap Tavanlı Cami ve Mescitler (Osmanlı Dönemi)". Akdeniz İnsani Bilimler Dergisi (2018) 407-425.

C. Parla, "Sivrihisar: Döner Eksenli Ahşap Tavanlı Camiler". Eski Yeni 2/17 (2010) 27-33.

G. Renda, Batıllașma Döneminde Türk Resim Sanatı 1700-1850. Ankara 1977.

L. Tay, "Erdemli-Güzeloluk Köyü’ndeki Türk Eserleri”. Zeitschrift für die Welt der Türken III/3 (2011) 265-286.

L. Tay, "Akseki-Sarıhacılar Köyü Cami”. Aksos Sosyal Bilimler Enstitüsü Dergisi (2017) 127-145.

L. Tay, "Kırşehir-Mucur Camileri". Art-e Sanat Dergisi 10 (2017) 691729.

L. Tay, "Gülşehir-Gümüşkent Köy Odası". III. Uluslararası Akdeniz Sanat Sempozyumu (24-25 Nisan 2018) (2018) 243-252.

F. Trzlak, "Antalya ve Korkuteli'nin 1835 Tarihindeki Köyleri (Muhtar ve İmamları ile Birlikte)”. Ed. A. K. Atılgan. Dünden Bugüne Antalya (2010) 145-148. Antalya.

T. M. Yıldız, 1839-1917 Arası İstanos (Korkuteli)'un İdari, Sosyal ve Ekonomik Durumu, Yayımlanmamış Doktora Tezi. Akdeniz Üniversitesi. Antalya 2014. 
